Огляди літератури, оригінальні дослідження, погляд на проблему

удК 618.145-006.3-06:616.441-091.8

DOI 10.11603/1811-2471.2017.v1.i3.8205

\title{
ЯКІСТЬ ЖИТТЯ ЖІНОК ІЗ ЕНДОМЕТРІОЗОМ ТА ПОРУШЕННЯМИ ФУНКЦІї ЩИТОПОДІБНОї ЗАЛОЗИ
}

\section{ДВНЗ «Тернопільський державний медичний університет імені І. Я Горбачевського МОз України»}

РЕзЮМЕ. Відповідно до мети і завдань у дослідження були включені 130 пацієнток репродуктивного віку із EM, яким була виконана органозберігаюча операція - консервативна кістектомія, із них 90 пацієнток мали порушення функції щитоподібної залози.

У ході проведеного дослідження встановлено вираженість впливу ЕМ на якість життя жінок - 33 (36,66 \%) пацієнтки основної та 11 (27,5 \%) групи порівняння до лікування характеризували якість свого життя як низьку, проти 5,0 \% пацієнток із контрольної групи.

Використання оптимізованого лікувального комплексу з використанням агоністів ГРГ та мастодинону для післяопераційної корекції гормонального дисбалансу має позитивний вплив на психоемоційні та вегетосудинні прояви, сприяє наближенню рівня всіх параметрів якості життя до показників контролю, що дозволило не тільки покращити основні показники гормонального гомеостазу, але і домогтися відновлення репродуктивної функції.

Запропонована нами схема лікування ЕМ відкриває нові перспективи у профілактиці розвиткугіперпластичних процесів ендо- та міометрія, запобігає зростанню відсотка імовірних рецидивів та нераціональних хірургічних втручань, і як наслідок, приводить до збереження репродуктивного потенціалу жінки.

КлючОВІ СЛОВА: генітальний ендометріоз; дисфункція щитоподібної залози; якість життя; психоемоційний стан.

Вступ. Проблема рецидивуючого ендометріозу турбує не лише пацієнтів, викликаючи у них тривалий біль, втрату репродуктивної функції, значні матеріальні витрати на медикаментозне лікування, повторні хірургічні втручання, а й лікарів, які курують таких хворих.

у нещодавно проведеному дослідженні «EndoCost» Всесвітнього дослідницького фонду ендометріозу (WERF) доведено, що витрати, пов'язані з лікуванням пацієнток з цією патологією у спеціалізованих клініках, практично зрівнялися 3 витратами, характерними для лікування таких хронічних захворювань як цукровий діабет. Крім економічних витрат, ендометріоз також суттєво впливає на соціальні та статеві аспекти життя жінок, стосунки, роботу і навчання [15].

Щорічно проводяться десятки клінічних досліджень, присвячених лікуванню ендометріозу та проблемам рецидивів і поширеності цього захворювання. Точних даних про поширеність ендометріозу в загальній популяції немає, адже це захворювання складно діагностувати і тривалий час воно перебігає безсимптомно. На думку ряду авторів [7, 3], поширеність ендометріозу серед жінок репродуктивного віку складає 2-20\%, а серед жінок 3 альгодисменореєю - 40-60 \%. У кожної третьої жінки з непліддям при прицільному дослідженні виявляють ендометріоз. У світі нараховується близько 300 млн жінок з діагнозом ендометріозу [5]. Наявні на сьогоднішній день види хірургічного та медикаментозного лікування цього захворювання ефективні далеко не у всіх випадках та супроводжуються високою частотою рецидивів.
У структурі гінекологічної захворюваності ендометріоз займає третє місце після запальних захворювань жіночих статевих органів і міом матки $[1,2]$. Число хворих із зовнішнім генітальним ендометріозом у загальній популяції складає 10$15 \%$, серед жінок з безпліддям - 25-60 \%, серед хворих з синдромом тазового болю - 60-80 \% [5, $8,11]$. Зовнішній генітальний ендометріоз $\epsilon$ медико-соціальною проблемою, оскільки часто трапляється у жінок молодого репродуктивного віку (21-40 років) і при вираженому ураженні геніталій призводить до частої і тривалої непрацездатності та безпліддя. Ендометріоз найчастіше зустрічається у жінок з високим соціальним рівнем, які займаються інтелектуальною працею, що супроводжується великим емоційним напруженням, хронічним стресом; живуть у несприятливому екологічному середовищі; мали невелику кількість пологів $[2,3,5,16,18]$.

Багаторічні тривалі дослідження не привели до формування остаточного уявлення щодо патогенезу захворювання, який представлений численними теоріями [1-3]. Разом з тим, клінічна картина не завжди відповідає тяжкості захворювання $[1-3,11]$. Наукові розробки останніх років свідчать, що у жінок, хворих на ендометріоз, частота настання вагітності значно нижча, ніж у здорових [1-3].

Результати останніх досліджень свідчать про істотну роль порушень імунного, гормонального, генетичного гомеостазу. Численні науковці достовірно доводять, що зовнішній генітальний ендометріоз розвивається на тлі порушеної імунної 
Огляди літератури, оригінальні дослідження, погляд на проблему

рівноваги, а саме активації В-лімфоцитарної системи при одночасному розвитку Т-клітинного імунодефіциту $[4,7,8,16]$. Для нормального функціонування практично всіх органів і систем, у тому числі й репродуктивних, необхідний нормальний рівень тиреоїдних гормонів [156]. Опосередкована роль у розвитку ендометріоїдних вогнищ належить дисфункції щитоподібної залози $[5,12,16,17]$. Відхилення від фізіологічної секреції тиреоїдних гормонів, які $\epsilon$ модуляторами дії естрогенів на клітинному рівні, можуть сприяти прогресуванню порушень гісто- і органогенезу гормоночутливих структур і формуванню ендометріозу $[1,10,12,14]$.

При нестачі гормонів щитоподібної залози відбувається порушення метаболізму естрогенів на клітинному рівні, що призводить до гіпоестрогенемії. Тривало персистуюча гіпоестрогенемія в умовах тканинної гіпоксії при субклінічному і клінічному (маніфестному) гіпотиреозі призводить до хронічної стимуляції і проліферації вогнищ в ендоміометрії і міометрії $[4,8]$. Гіпофункція щЗ призводить до порушення периферійного метаболізму естрогенів $[10,11,16]$.

Однак наукові дані про стан тиреоїдного статусу при зовнішньому генітальному ендометріозі і його роль у виникненні, розвитку і перебігу захворювання вельми нечисленні і суперечливі, що визначає актуальність цього дослідження.

Метою нашого дослідження було вивчення якості життя жінок, хворих на ендометріоз, у поєднанні з дисфункцією щитоподібної залози та зниження частоти рецидивування захворювання на підставі удосконалення і впровадження алгоритму діагностичних, лікувально-профілактичних та реабілітаційних заходів з використанням сучасних ендоскопічних технологій та медикаментозної корекції.

Матеріал і методи. На першому етапі роботи було проведено ретроспективний аналіз частоти та структури захворюваності на ЕМ за даними гінекологічних відділень лікувальних закладів м. Тернопіль. Це дозволило не тільки сформувати групи ризику, а й виділити провідні критерії метаболічних та гормональних порушень гомеостазу у репродуктивному віці.

В умовах гінекологічного відділення з центром лікування ендометріозу було проведено активне скринінгове обстеження 360 жінок. У $86 \%$ обстежених було діагностовано ряд ендокринних порушень функції щитоподібної залози, що свідчить про високу частоту поєднання ЕМ та гормональних порушень, а також про важливість проведення активних скринінгових обстежень у даної категорії пацієнток.

Відповідно до мети і завдань дослідження із даної групи пацієнток у дослідження були відібра- ні 130 жінок репродуктивного віку із EM, яким проводили органозберігаючу операцію - консервативну кістектомію; з них 90 мали порушення функції щитоподібної залози.

У контрольну групу увійшли 20 пацієнток репродуктивного віку без супутньої гінекологічної та соматичної патології.

Усі обстежені були поділені на основну групу та групу порівняння. До основної групи увійшли 90 хворих з 3-4 ст. ендометріозу та патологією щитоподібної залози.

В групу спостереження входили хворі з основними симптомами ендометріозу: больовим синдромом, диспареурією, порушенням функції суміжних органів, психоневрологічними порушеннями, розладами репродуктивної функції (непліддя та невиношування).

Усім обстеженим хворим на першому етапі було проведено хірургічне втручання, використано метод вилущування ендометріоїдної кісти в межах здорових тканин з мінімальною коагуляцією за ходом рани. Хворі були поділені на дві групи, зіставні за антропометричними даними, гінекологічним, репродуктивним, соматичним анамнезом, усі мали зовнішній ендометріоз 3-4 ступенів у вигляді ендометріоїдних кіст розміром більше 4 см, залежно від комплексного підходу до реабілітаційного післяопераційного лікування. Первинне непліддя було у 69 \% жінок, вторинне -у $31 \%$.

Пацієнтки першої (50 жінок) та другої (40 жінок) досліджуваних груп у післяопераційному періоді отримували агоністи гонадотропін-рилізинг гормонів (а-ГнРГ) - препарат Декапептил у дозі 3,75 мг підшкірно кожні 28 днів впродовж 2 місяців.

Пацієнтки другої групи для усунення та зменшення клінічних проявів побічних ефектів, пов'язаних із дією вказаних препаратів, а також для досягнення позитивного впливу на гормональний та психоемоційний статус і корекції вегетативних порушень, що супроводжують метаболічні розлади у даної категорії жінок, у комплексі гормональної післяопераційної терапії додатково отримували препарат екстракту трави Vitex agnus castus BNO 1095.

Пацієнтки третьої групи порівняння у післяопераційному періоді отримували стабілізаційну традиційну терапію комбінованими монофазними гормональними контрацептивами згідно із загальноприйнятими національними стандартами.

Механізм дії Vitex agnus castus BNO 1095 багатокомпонентний та багаторівневий, цей препарат впливає на гормональний баланс організму, забезпечуючи ліквідацію гіперпролактинемії, нормалізацію гонадотропінсинтезувальної функ- 
Огляди літератури, оригінальні дослідження, погляд на проблему

ції гіпофіза, непряму естрогенну дію, не порушуючи механізмів його регуляції. Схема використання - 1 таблетка 2 рази на добу протягом 90 днів рег os. Препарат позитивно впливає на психоемоційний статус, стан вегетативної нервової системи, сприяє поліпшенню загального самопочуття, зменшенню втомлюваності, уразливості, збільшенню фізичної та розумової працездатності, покращенню пам'яті.

Поєднання вищеперерахованих препаратів у одній програмі лікування ЕМ не застосовували, і це відкриває нові перспективи у профілактиці розвитку гіперпластичних процесів ендо- і міометрія, збільшення відсотка імовірних рецидивів та нераціональних оперативних втручань, i, як наслідок, збереження репродуктивного потенціалу жінки.

Результати й обговорення. Основними скаргами в усіх трьох групах пацієнток основної групи із ЕМ на тлі дисфункції ЩЗ були больовий синдром (56-62,2 \%), надмірні кров'янисті виділення (6774,44 \%), анемія (Нb<100 г/л) (48-53,33 \%) та порушення функції сусідніх органів (32-35,55 \%). Досліджувані групи до хірургічного втручання не відрізнялися статистично значимо за окремими клінічними проявами, крім симптоматики кровотеч та больового фактора.

Питання психоемоційного стану жінок із ЕМ $\epsilon$ досить актуальним, адже проблема залишається не зовсім вивченою і, до того ж, потребує пошуку способів корекції задля покращення прогнозу та якості життя жінок із даною патологією.

Всі пацієнтки контрольної, основної груп та групи порівняння на момент обстеження перебували у шлюбі, 46,92 \% жінок (61 особа) мали вищу освіту.

Тривожними розладами та схильністю до депресії можна пояснити високу частоту порушень сну у $(52,30 \pm 4,52) \%$ жінок (68 осіб). У результаті опитування виявилося, що суб'єктивно психоло- гічно здоровими вважали себе тільки 4 жінки $(4,44 \%)$ із ЕМ та порушеннями функції Щ3, всі інші мали психологічні розлади різного ступеня вираженості пограничного рівня. Після консультації психотерапевта та психолога соматизовані розлади було констатовано у 27 пацієнток (30,0 \%), депресивний епізод середнього ступеня тяжкості у 27 пацієнток (30,0 \%), іпохондричні розлади - у 4 пацієнток (4,44%); в поодиноких випадках відмічено тривалий постстресовий розлад, генералізований тривожний розлад, панічний розлад, обсесивно-фобічний розлад, легкий депресивний епізод, неврастенію.

Вивчення основних психосоматичних факторів показало вищий рівень депресії і реактивної тривожності серед жінок основної досліджуваної групи, що $\epsilon$ несприятливим психоемоційним фактором і потребує відповідної психокорекції.

У структурі гінекологічних захворювань ЕМ $\epsilon$ найчастішим захворюванням жінок репродуктивного віку після запальних процесів органів малого таза, а відносно стерта симптоматика та неможливість реалізації репродуктивної функції призводять до значного зниження якості життя таких пацієнток.

Загалом якість життя пацієнток із ЕМ та порушеннями функції ЩЗ є значимо нижчою, ніж у здорових жінок. Це погіршення залежить не тільки від болю, а й від емоційного стану, представленого насамперед тривожно-депресивними розладами. Однією із причин болю, незадоволеності станом свого здоров'я може бути відсутність терапії, спрямованої на корекцію метаболічних розладів, та психотерапії.

Як свідчать дані, наведені в таблиці 1, наявні значні відмінності ЯЖ жінок із ЕМ та порушеннями функції щз за шкалою GeneralHealth (GH) (загальна оцінка здоров'я); пацієнтки з больовим розладом достовірно частіше оцінювали своє здоров'я як посереднє $(p<0,001)$.

Таблиця 1. Вегетосудинні та психосоматичні прояви психологічної дезадаптації, \%

\begin{tabular}{|c|c|c|c|c|c|c|}
\hline \multirow[t]{2}{*}{ Ознака } & \multicolumn{2}{|c|}{$\begin{array}{c}\text { Основна група } \\
(n=90)\end{array}$} & \multicolumn{2}{|c|}{$\begin{array}{c}\text { Група порівняння } \\
(n=40)\end{array}$} & \multicolumn{2}{|c|}{$\begin{array}{c}\text { Контрольна група } \\
(n=20)\end{array}$} \\
\hline & a6c. & $\%$ & a6c. & $\%$ & a6c. & $\%$ \\
\hline Швидка втомлюваність & 67 & $74,44^{*}$ & 35 & $87,5^{*}$ & 2 & 10,0 \\
\hline Порушення сну & 79 & $87,7^{*}$ & 29 & $72,5^{*}$ & - & - \\
\hline Дратівливість & 67 & $74,44^{*}$ & 26 & $65,0 *$ & - & - \\
\hline Поганий настрій, депресія & 69 & $76,66^{*^{\circ}}$ & 18 & $45,0 *$ & - & - \\
\hline Відсутність апетиту & 36 & $40,0 *$ & 14 & $35,0 *$ & 1 & 5,0 \\
\hline Тривожність & 68 & $75,5^{*^{\circ}}$ & 17 & $42,5^{*}$ & 1 & 5,0 \\
\hline Емоційна лабільність & 82 & $91,11 *^{\circ}$ & 19 & $47,5^{*}$ & - & - \\
\hline Алергічні реакції & 29 & $32,2^{* \circ}$ & 9 & $22,5^{*}$ & - & - \\
\hline Серцебиття в спокої & 29 & $32,2 *^{\circ}$ & 7 & $17,5^{*}$ & - & - \\
\hline Кардіалгія & 39 & $43,33^{*}$ & 11 & $27,5^{*}$ & - & - \\
\hline Масталгія & 31 & $34,4^{*^{\circ}}$ & 9 & $22,5^{*}$ & - & - \\
\hline
\end{tabular}


Огляди літератури, оригінальні дослідження, погляд на проблему

У ході проведеного дослідження встановлено, що ЕМ чинить виражений вплив на якість життя жінок. Загалом 33 (36,66 \%) пацієнтки основної та 11 $(27,5 \%)$ пацієнток групи порівняння до лікування оцінювали якість життя як низьку, тоді як подібну характеристику якості життя давали 5,0 \% пацієнток із контрольної групи. Закономірно, що лише $8(6,15 \%)$ жінок із ЕМ обох груп характеризували якість свого життя як високу, тоді як у контрольній групі якість свого життя як високу оцінювали 40,00 \% (8 пацієнток). Найвищий ступінь незадоволеності був за показником загального здоров'я 29,23 \% (38 пацієнток) випадків, дещо менший - у галузях професійної та фізичної активності $22,30 \%$ (29 пацієнток), а також у емоційній сфері 29,23\% (38 пацієнток).

Зниження якості життя пацієнтки із ЕМ у половині випадків пов'язували із болем, дискомфортом при статевому акті, зниженням лібідо, постійними метрорагіями та епізодами міжменструальних кровомазань.

Виявлена пряма залежність показників загальної якості життя, а також у сферах здоров'я та емоцій, від віку пацієнток.

Приєднання ускладнень підвищує рівень стресу, а необхідність хірургічного оздоровлення $\epsilon$ передумовою для психосоматичних порушень. Це створює додаткові фактори ризику для розвитку психосоціального дистресу у пацієнток даної групи. Однією із причин збереження болю, незадоволеності станом свого здоров'я може бути відсутність терапії для корелювання метаболічних розладів та адекватної психотерапії та психокорекції.

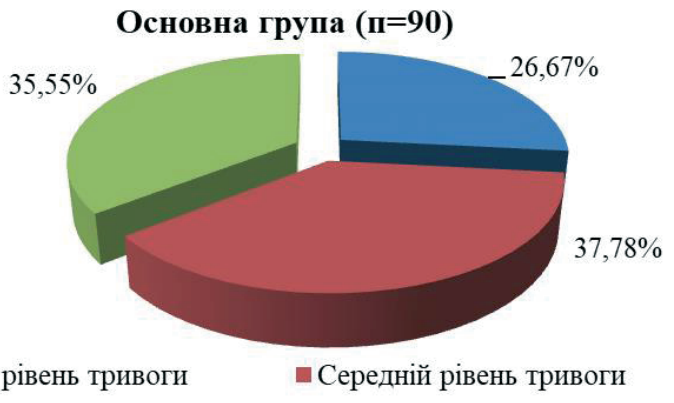

— Високий рівень тривоги

匹 Низький рівень тривоги
Серед психоемоційних та вегетосудинних проявів у жінок обох досліджуваних груп найчастіше відмічали швидку втомлюваність (74,44 \%), порушення сну $(87,7 \%)$, дратівливість та зміну настрою $(74,44 \%)$, а у групі порівняння $(72,5 \%)$, крім того, у жінок із ожирінням переважали емоційна лабільність $(91,11 \%)$, тривожність $(75,5 \%)$ та депресивні прояви (76,66 \%).

Характеризуючи окремі показники психоемоційного статусу слід зазначити, що середній показник депресії в основній групі склав $(24,42 \pm 1,12) 6 а$ лів, у групі порівняння - $(20,12 \pm 1,13)$ балів, що свідчить про помірний рівень депресії у жінок обох досліджуваних груп та вірогідно відрізняється у 2,5 раза від показника у групі здорових жінок $(6,96 \pm 0,22)(p<0,05)$ (табл. 1).

Аналіз ступеня психологічної дезадаптації за тестом Спілбергера виявив високий рівень тривожності - $(50,20 \pm 3,18)$ балів у групі порівняння та $(53,18 \pm 4,12)$ бали - у основній групі, що вірогідно відрізняється від показника контрольної групи $(20,14 \pm 1,06)$ бали $(p<0,05)$.

Дані, наведені на рисунку 1, свідчать, що у жінок із ЕМ має місце більш виражена психотривожна ситуація із найвагомішими відхиленнями. При верифікації клінічних ознак метаболічних порушень виявлено, що більше половини пацієнток відмічають помірно виражений та середній ступені тривоги, а також зростання частки тяжких проявів тривожності у пацієнток основної групи.

Загалом у таких жінок частіше виявляють ознаки депресивних та астенічних рис, ніж у жінок контрольної групи.

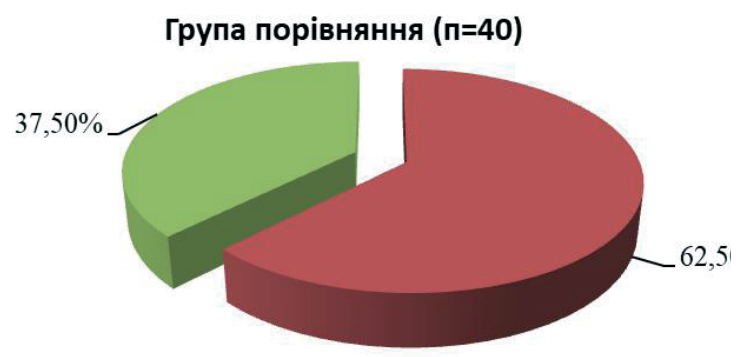

- Середній рівень тривоги

Рис. 1. Оцінка параметрів якості життя у жінок досліджуваних груп.

Висновки. У жінок із ЕМ та порушеннями функції щз має місце більш вагома психотривожна ситуація, яка визначає високий відсоток психоемоційних та вегетосудинних проявів, підвищує акцент соматичних відчуттів, зокрема кардіалгії та масталгії, зі зростанням у 3 рази частки помірно виражених та тяжких проявів тривожності (75,56\%) і депресивних станів $(76,67 \%)$, що призводить до зниження як фізичного, так i, значною мірою, пси- хічного компонента якості життя. Використання оптимізованого лікувального комплексу з використанням агоністів ГРГ та Vitex agnus castus BNO 1095 (Мастодинону) у післяопераційній корекції гормонального дисбалансу позитивно впливає на психоемоційні та вегетосудинні прояви, сприяє наближенню рівня всіх параметрів якості життя до показників контролю, що дозволило не тільки покращити основні показники гормонального 
Огляди літератури, оригінальні дослідження, погляд на проблему

гомеостазу, а й домогтися відновлення репродуктивної функції.

Перспективи подальших досліджень. Запропонована нами схема лікування ЕМ відкриває нові перспективи у профілактиці розвитку гіпер-

\section{ЛІТЕРАТУРА}

1. Эндометриоз: диагностика, лечение и реабилитация / Л. В. Адамян, Е. Н. Андреева, И. А. Аполихина [и др.] // Федеральные клинические рекомендации по ведению больных. - Москва, 2013. - 65 с.

2. Бойко В. І. Сучасні аспекти лікування ендометріозу яєчників / В. І. Бойко, І. М. Нікітіна, О. В. Єжова // Акушерство. Гінекологія. Генетика. - 2016. - № 3 (2). - С. 47-51.

3. Органозберігаюче хірургічне лікування та частота рецидивів ендометріозу / А. В. Бойчук, О. Ю. Курило, О. М. Корман, О. І. Хлібовська // Актуальні питання педіатрії, акушерства та гінекології. - 2015. - № 2. - С. 73-77.

4. Бойчук А. В. Оваріальний резерв жінок з ендометріоїдними кістами / А. В. Бойчук, О. Ю. Курило // Збірник наукових праць Асоціації акушерів-гінекологів України. - 2016. - № 2 (38). - С. 60-66.

5. Галкина Н. В. Диффузный эутиреоидный 306 (эпидемиология, этиология и патогенез, роль генетических факторов в развитии, лечение) / Н. В. Галкина, Н. В. Мазурина, Е. А. Трошина // Пробл. эндокринологии. - 2006. - Т. 52, № 4. - С. 49-56.

6. Дерябина Е. Г. Современные представления о влиянии половых стероидов на патогенез заболеваний щитовидной железы у женщин / Е. Г. Дерябина, Н. В. Башмакова // Росс. вест. акуш. гинек. - 2008. - Т. 8, № 6. - C. 52-55.

7. Запорожан В. М. Національний консенсус щодо ведення пацієнток із ендометріозом / В. М. Запорожан, Т. Ф. Татарчук, В. В. Камінський // Репродуктивная эндокринология. - 2015. - № 4. - С. 7-12.

8. Ищенко А. И. Еффективность комбинированного лечения наружного эндометриоза с синдромом хронических тазовых болей с использованием агониста гонадотропин-рилизинг гормона Декапептил-депо /

\section{REFERENCES}

1. Adamyan, L.V., Andreyeva, Ye.N., Apolikhina, I.A., Bezhenar, V.F., Gevorkyan, M.A., Gus, A.I. \& Demidov, V.N. (2013). Endometrioz: diagnostika, lecheniye i reabilitatsiya [Endometriosis: diagnosis, treatment and rehabilitation]. Federalnyye klinicheskiye rekomendatsii po vedeniyu bolnykh - Federal Clinical Guidelines for Managing Patients. Moscow [in Russian].

2. Boiko, V.I., Nikitina, I.M. \& Yezhova, O.V. (2016). Suchasni aspekty likuvannia endometriozu yaiechnykiv [Modern aspects of the treatment of ovarian endometriosis]. Akusherstvo. Hinekolohiia. Henetyka. - Obstetrics. Gynecology. Genetics, 3 (2), 47-51 [in Ukrainian].

3. Boychuk, A.V., Kurylo, O.Yu., Korman, O.M. \& Khlibovska, O.I. (2015). Orhanozberihaiuche khirurhichne likuvannia ta chastota retsydyviv endometriozu [Organ-preserving surgical treatment and the frequency of пластичних процесів ендо- і міометрія, сприяє зменшенню відсотка імовірних рецидивів та нераціональних хірургічних втручань, і, як наслідок, збереженню репродуктивного потенціалу жінки.

А. И. Ищенко, Е. А. Кудрина, У. А. Абдуллаева // Жіночий лікар. - 2006. - № 6 (8). - С. 8-11.

9. Ищенко А. И. Современные проблемы наружного генитального эндометриоза / А. И. Ищенко, Е. А. Кудрина, И. В. Станоевич // Акуш. и гинек. - 2007. - № 5. - С. 67-73.

10. Леонов Б. В. Применение а-ГнРГ при бесплодии / Б. В. Леонов, В.И.Кулаков, В. Ю. Смольникова // Акушерство и гинекология. - 2003. - № 4. - С. 1-4.

11. Наказ Міністерства охорони здоров'я України 06.04.2016 № 319 Уніфікований клінічний протокол первинної, вторинної (спеціалізованої) та третинної (високоспеціалізованої) медичної допомоги. Тактика ведення пацієнток з генітальним ендометріозом.

12. Пашков В. М. Современные представления об этиологии и патогенезе генитального эндометриоза / В. М. Пашков, В. А. Лебедев // Вопр. гинек., акуш. и перинт. - 2007. - Т. 6, № 3. - С. 52-61.

13. Fernandez I. Living with endometriosis: The perspective of male partners / I. Fernandez, C. Reid, S. Dziurawiec // J. Psychosom. Res. - 2006. - Vol. 61 (4). - P. 433-438.

14. Hickey M. Endometriosis / M. Hickey, K. Ballard, C. Farquhar // BMJ. - 2014. - Vol. 348. - P. g1752.

15. Stratton P. Chronic pelvic pain and endometriosis: translational evidence of the relationship and implications / P. Stratton, K. J. Berkley // Hum. Reprod. Update. 2011. - Vol. 17 (3). - P. 327-324.

16. Trokoudes K. M. Infertility and thyroid disorders / K. M. Trokoudes, N. Skordis, M. K. Picoloc // Curr. Opin. Obstet. Gynecol. - 2006. - Vol. 18, No. 4. - P. 446-451.

17. Wu Y. Transcriptional characterizations of differences between eutopic and ectopic endometrium / Y. Wu, A. Kajdacsy-Balla, E. Strawn // Endocrinology. - 2006. Vol. 47, № 1. - P. 232-246.

endometriosis relapse]. Aktualni pytannia pediatrii, akusherstva ta hinekolohii - Actual Issues of Pediatrics, Obstetrics and Gynecology, 2, 73-77 [in Ukrainian].

4. Boichuk, A.V. \& Kurylo, O.Yu. (2016). Ovarialnyi rezerv zhinok z endometrioidnymy kistamy [Ovarian reserve of women with endometrioid cysts]. Zbirnyk naukovykh prats Asotsiatsii akusheriv-hinekolohiv Ukrainy - Collection of Scientific Works of the Association of Obstetricians-Gynecologists of Ukraine, 2 (38), 60-66 [in Ukrainian].

5. Galkina, N.V., Mazurina, N.V. \& Troshina, Ye.A. (2006). Diffuznyy eutireoidnyy zob (epidemiologiya, etiologiya i patogenez, rol geneticheskikh faktorov v razvitiyi, lecheniye) [Diffuse euthyroid goiter (epidemiology, etiology and pathogenesis, the role of genetic factors in development, treatment)]. Probl. endokrinologii - Problems of Endocrinology, (52), 4, 49-56 [in Russian]. 
Огляди літератури, оригінальні дослідження, погляд на проблему

6. Deryabina, Ye.G. \& Bashmakova, N.V. (2008). Sovremennyye predstavleniya o vliyanii polovykh steroidov na patogenez zabolevaniy shchitovidnoy zhelezy u zhenshchin [Modern ideas about the effect of sex steroids on the pathogenesis of thyroid diseases in women]. Ross. vest. akush. ginek. - Russian Journal of Obstetricians-Gynecologists (8), 6, 52-55 [in Russian].

7. Zaporozhan, V.M., Tatarchuk, T.F. \& Kaminskyi, V.V. (2015). Natsionalnyi konsensus shchodo vedennia patsiientok iz endometriozom [National Consensus on the Management of Patients with Endometriosis]. Reproduktivnaya endokrinologiya - Reproductive Endocrinology, 4, 7-12 [in Ukrainian].

8. Ishchenko, A.I., Kudrina, Ye.A. \& Abdullayeva, U.A. (2006). Effektivnost kombinirovonnogo lecheniya naruzhnogo endometrioza s sindromom khronicheskikh tazovykh boley s ispolzovaniyem agonista gonadotropin-rilizing gormona Dekapeptil-depo [Efficiency of combined treatment of external endometriosis with the syndrome of chronic pelvic pain with the use of agonist gonadotropin-releasing hormone Decapeptil Depot]. Zhinochyi likar - Women's doctor, 6 (8), 8-11 [in Russian].

9. Ishchenko, A.I., Kudrina, Ye.A. \& Stanoyevich, I.V. (2017). Sovremennyye problemy naruzhnogo genitalnogo endometrioza [Modern problems of external genital endometriosis]. Akush. i ginek. - Obstetrics and Gynecology, 5, 67-73 [in Russian].

10. Leonov, B.V., Kulakov, V.I. \& Smolnikova, V.Yu. (2003). Primeneniye a-GnRG pri besplodii [Application of a-GnRH in infertility]. Akushcherstvo i ginekologiya - Obstetrics and Gynecology, 4, 1-4 [in Russian].
11. Nakaz Ministerstva okhorony zdorovia Ukrainy 06.04.2016 № 319 Unifikovanyi klinichnyi protokol pervynnoi, vtorynnoi (spetsializovanoi) ta tretynnoi (vysokospetsializovanoi) medychnoi dopomohy. Taktyka vedennia patsiientok $z$ henitalnym endometriozom [Order of the Ministry of Health of Ukraine 06.04.2016 No. 319 Unified clinical protocol of primary, secondary (specialized) and tertiary (highly specialized) medical care. Tactics of patients with genital endometriosis]. [in Ukrainian].

12. Pashkov, V.M. \& Lebedev, V.A. (2007). Sovremennyye predstavleniya ob etiologii i patogeneze genitalnogo endometrioza [Modern ideas about the etiology and pathogenesis of genital endometriosis]. Vopr. ginek., akush. i perint. - Issues of Gynecology, Obstetrics and Perinatology, (6), 3, 52-61 [in Russian].

13. Fernandez, I., Reid, C. \& Dziurawiec, S. (206). Living with endometriosis: The perspective of male partners. J. Psychosom. Res., 61 (4), 433-438.

14. Hickey, M., Ballard, K. \& Farquhar, C. (2014). Endometriosis. BMJ, 348, g1752.

15. Stratton, P. \& Berkley, K.J. (2011). Chronic pelvic pain and endometriosis: translational evidence of the relationship and implications. Hum. Reprod. Update, (17), 3, 327-324.

16. Trokoudes, K.M., Skordis, N. \& Picoloc, M.K. (2006). Infertility and thyroid disorders. Curr. Opin. Obstet. Gynecol, (18), 4, 446-451.

17. Wu, Y., Kajdacsy-Balla, A. \& Strawn, E. (2006). Transcriptional characterizations of differences between eutopic and ectopic endometrium. Endocrinology, (47), 1, 232-246.

\title{
КАЧЕСТВО ЖИЗНИ ЖЕНЩИН С ЭНДОМЕТРИОЗОМ И НАРУШЕНИЯМИ ФУНКЦИИ ЩИТОВИДНОЙ ЖЕЛЕЗЫ
}

๑А. В. Бойчук, О. Ю. Курило

\author{
ГВУз «Тернопольский государственный медицинский университет имени И. Я. Горбачевского МОЗ \\ Украины»
}

РЕЗЮМЕ. В соответствии с целью и задачами, в исследование были включены 130 пациенток репродуктивного возраста с ЭМ, которым была выполнена органосохраняющая операция - консервативная кистэктомия, из них у 90 пациенток имелись нарушения функции щитовидной железы.

В ходе проведенного исследования установлена выраженность влияния ЭМ на качество жизни - 3 (36,66 \%) пациенток основной та 11 (27,5 \%) группы сравнения до лечения характеризовали качество своей жизни как низкое, против 5,0 \% пациенток из контрольной группы.

Использование оптимизированного лечебного комплекса с использованием агонистов ГРГ и мастодинона для послеоперационной коррекции гормонального дисбаланса положительно влияет на психоэмоциональные и вегетососудистые проявления, способствует приближениюуровня всехпараметров качества жизни к показателям контроля, что позволило не только улучшить основные показатели гормонального гомеостаза, но и добиться восстановления репродуктивной функции

Предложенная нами схема лечения ЭМ открывает новые перспективы в профилактике развития гиперпластичних процессов эндо- и миометрия, предотвращает рост процента возможных рецидивов и нерациональних хирургических вмешательств, и, как следствие, приводит к сохранению репродуктивного потенциала женщины.

КЛЮЧЕВЫЕ СЛОВА: генитальный эндометриоз; дисфункция щитовидной железы; качество жизни; психоэмоциональное состояние. 


\section{QUALITY OF LIFE OF WOMEN WITH ENDOMETRYOSIS AND DIFFICULTIES} OF THE THYROID DISEASE FUNCTION

\section{Horbachevsky Ternopil State Medical University}

SUMMARY. According to the purpose and aims of the study, 130 patients of reproductive age with EM were included in the study, who underwent organo-preservation surgery - a convex cystectomy. Among them 90 patients were with a violation of the function of the thyroid gland.

In the course of the investigation, it has been updated, as much as the affected effect employs EM in any life of women. Thus, in the general group of 3 (36.66 \%) patients in the main group and $11(27.5 \%)$ in the treatment comparison group, each life was considered as low, while only $5.0 \%$ of the control subjects had a similar characteristics of life.

The use of an optimized treatment complex using GHG and mastodinone agonists in postoperative correction of hormonal imbalances has a positive effect on psychoemotional and vegetative-vascular manifestations, contributed to the approximation of the level of all parameters of the quality of life to the control indicators, which allowed not only to improve the basic indicators of hormonal homeostasis, but also to achieve restoration of reproductive function.

Our proposed treatment scheme for EM is not activated, and it opens new prospects in the prevention of the development of hyperplastic processes of endometrium, their growth and the growth of the percentage of probable relapses and non-surgical operative interventions, and as a consequence, preserving the reproductive potential of a woman.

KEY WORDS: genital endometriosis; dysfunction of thyroid gland; quality of life; psychoemotional condition.

Отримано 05.07.2017 